\title{
Selection Model for Optimization of the Gene Bank of Cherry (Prunus cerasus L.) and plum (Prunus domestica L.) in the Low Volga Region
}

\author{
Andrey Solonkin, Olga Nikolskaya, and Yelena Kikteva
}

Federal State Budget Scientific Institution Federal Scientific Center of agroecology, complex meliorations and protective afforestation of Russian Academy of Sciences, Volgograd, Russia

\section{Abstract}

The researchers of the Scientific Research Institute of Agriculture of the Low Volga region -- the branch of FSC of agroecology of RAS -- have developed the regulations for the selection model of optimization of genetic pool and created a number of varieties of cherry and plum by hybridization of local and southern varieties and by use of hybrids of free pollination. The optimization of gene bank of cherry and plum on the basis of the study of genetic biodiversity and regulations for the selection

Corresponding Author:

Andrey Solonkin

mishamax73@mail.ru

Received: 25 October 2019

Accepted: 15 November 2019

Published: 25 November 2019

Publishing services provided by Knowledge E

(c) Andrey Solonkin et al. This article is distributed under the terms of the Creative Commons Attribution License, which permits unrestricted use and redistribution provided that the original author and source are credited.

Selection and Peer-review under the responsibility of the AgroSMART 2019 Conference Committee. model and programs provides the adaptation of the new developed varieties for creation of industrial crops in agrosystems of the Low Volga and other regions of Russia. The catalog of assortment has been developed and the six varieties of garden plum (Prunus domestica L.) regionalized, including Volgogradskaya, Bogatyrskaya, and Vengerka korneyevskaya varieties, as well as a number of other ones that have been created during hybridization of the local varieties of the Volga region, such as, Volzhskaya sinyaya, Ternosliv letniy, Ternosliv osenniy with the most adaptive introduced varieties. The new varieties and elites (best speciments) of sour cherry (Prunu scerasus L.): Loznovskaya, Dubovskaya krupnoplodnaya, Melodiya, Lyubimitsa, Peskovatskaya, Dubovochka, Temnookrashennaya, Sharada, Pamyat Zhukovoy -- have been selected by intervarietal hybridization and by sowing of seeds collected during free pollination of the following varieties: Zhukovskaya, Lyubskaya, Krasa Severa, Shirpotreb chernaya, Ujfeherto furtos. The above mentioned forms contributed to richer assortment of garden plum and sour cherry in the Low Volga region, meaning adaptive, high-yielding, high quality varieties of universal use. There is a good reason to use the above mentioned assortment as the integrated donors during development of selection programs aimed on continued improvement of varieties of stone fruit crops.

Keywords: monitoring, genealogy, stone fruit crops, donor, source, hybridization, large-fruiting.

\section{Introduction}

The development of the regulations on the basis of monitoring and modeling of the S OPEN ACCESS 
ameliorative, fruit bearing, medicine, and others) is of a great importance for optimization of degraded agrarian and urban ecosystems [1, 2].

The conditions of the southern regions, the Low Volga region included, are favorable for cultivation of stone fruit plants: plums and cherries. The above mentioned crops produce high yields of high quality fruits both for eating fresh and for processing because of favorable combination of soil-climatic conditions (soils of light granulometric composition, long summer period, pretty mild winters with the temperature not lower than $-25{ }^{\circ} \mathrm{C}$, very seldom the frost is severe -- about $\left.--30 \ldots . .-35{ }^{\circ} \mathrm{C}\right)[3--5,8]$. The fruits of cherries and plums were produced in large amounts in late $19^{\text {th }}--$ early $20^{\text {th }}$ in the Astrakhan and Tsaritsyn provinces and shipped up the Volga River right up to Kazan [6].

The biodiversity of above mentioned crops was deficient and poor for a long time and included old varieties that did not fully comply with users` demands. The winterresistant local and old Russian varieties were of middling eating and industrial qualities of fruits, while the attempts of cultivation of their best foreign varieties resulted in their frostkilling during severe winters of $1954\left(--37^{\circ} \mathrm{C}\right.$ ), 1968 (open winter; $\left.--28 \ldots .--30{ }^{\circ} \mathrm{C}\right), 1978$ $\left(--33 \ldots--35{ }^{\circ} \mathrm{C}\right), 2005\left(--28 \ldots-.-33^{\circ} \mathrm{C}\right)$. The above mentioned circumstances substantiated the objective of selection and improvement of varieties of cherries and plums which would be adapted to unfavorable local conditions, such as, winter frosts and summer droughts [9].

In order to reach the research purpose the following tasks were set:

1. study of varieties of the current assortment of cherries and plums and determination of valuable forms for the purposes of selection;

2. choice of paternal pairs for the purposes of hybridization;

3. hybridization of chosen pairs and sowing of seeds of the best varieties from free pollination to create new genotypes of Prunus cesarus L. and Prunus domestica L.

\section{Methods and Equipment}

The optimization and completion of biodiversity can be achieved by different methods -- by enlistment of indirect forms of cultural and wild plants and by selection for improvement of the actual assortment. The study and improvement of the assortment of cultural fruit crops, including Prunus cerasus L. and Prunus domestica L., have been started since 50 s of the last century in the Low Volga region $[3,7]$. First, the goal of study 
of a number of varieties of cherries and plums was developed, as well as determination of valuable varieties of local origin, and foreign and Russian selection. From 1993 to 2017 the Scientific-Research Institute of Agriculture of the Low Volga region -- the branch of FSC of agroecology of RAS had studied about 100 of genotypes of different selection centers of sour cherry (Prunus cerasus L.) and over 100 of genotypes of different selection centers of garden plum (Prunus domestica L.). The hybrid fund of cherries included over 2000 of hybrid seedlings, that of plums -- over 1500 of hybrid seedlings. The number of index trees of each variety equaled from 6 to 10 plants with four-fold repetition [10]. Within the hybrid fund each hybrid seedling was presented in a single exemplar [11].

The improvement of the current assortment of stone crops was fulfilled by a purposeful hybridization according to the traditional methods of selection: interspecific selection (between varieties of plum ( $P$. domestica L.) and blackthorn ( $P$. spinosa L.), cherry (P. cerasus L.) and mazzard cherry (P. avium L.)), and intervarietal selection (different varieties of plum ( $P$. domestica $\mathrm{L}$.) between each other and cherry ( $P$. cerasus $L$.) between each other) [11, 12]. The procedure of hybridization was identical for all methods and included the following stages: isolation of buds of female plants, castration of female flowers, storing up of pollen, control of pollen viability before pollination, pollination. The isolation of buds was conducted 5--6 days prior to flowering using cheesecloth or butter paper bags. For a single family of stone crops between 1500 and 2000 of flowers were isolated. The pollen was stored up from a male plant accounting one flower of male plant for two flowers of female plant, five days prior the pollination. The pollen was stored in an exsiccator filled with calcium chloride or sulfuric acid so that it might keep its viability for a long time. The viability of pollen was checked prior to pollination by its greensprouting during 4--5 hours in $15 \%$ solution of sucrose with adding of 0.1 $\mathrm{mg}$ of boric acid per $100 \mathrm{ml}$ of the solution. After the pollination the two inspections were conducted after which the insulators were removed. The ovary hybrid seeds were sowed into a nursery for preliminary selection during two years. The best seedlings were planted in a selection garden for selection of valuable industrial features, such as yielding, quality of fruits, resistance to abiotic and biotic stress-factors [11].

The degree of resistance of initial forms and hybrids of cherry (P. cerasus $L$.) and plum (P. domestica L.) to unfavorable winter factors was estimated on a natural background in the open ground according to the methods of primary study of varieties. The frostand winter-resistance of shoots, flower buds, and total state of trees was estimated with a five-point scale. The industrial features of the variety were also estimated, such as 
yielding, early maturity, terms of ripening, quality of fruits; biometrical characteristics of trees -- intensity and character of growth, type of fruitiness, and other criteria [10].

The forwarded creation of new varieties of stone crops was based on the use of the method of analytical selection (genealogical method). The background of preliminary selection was based on the conception of genetic determination of valuable characteristics necessary for the use during hybridization [15]. The hybridological method of research generally used in genetic analysis is not effective enough when dealing with many-year fruit a crop that is why the use of knowledge in genealogy of varieties was reasonable both for theory and practice of the process of selection. The genealogical method provided the determination of genotypes which met the requirements of the donors, and gave the opportunity to suppose the probability of display of valuable characteristics of predecessors in the phenotypes of individuals of the future generations of descendants. Using genealogical method, in addition to display of the characteristics of paternal varieties in the progeny, the great significance was attached to the presence of forepaternal characteristics in the hybrids, which were missing in the paternal forms $[13,15]$.

\section{Results}

There were a number of valuable varieties developed in the Dubovsky control station of NVNIISKH as a result of selection works with plums and cherries [3, 14, 19]. It was necessary to summarize the experience in creation of winter-resistant and high quality varieties with participation of local forms in specific conditions of the Low Volga region. To conduct the genetic analysis of the created gene bank there was used the genealogical analysis which was effective during study of the gene bank of fruit crops [15].

During the selection of cherries the hybridization of adaptive, large-fruited varieties with the local high-adaptive forms turned to be the most effective [8, 21, 22]. As for our research, those were the old Russian and West European forms -- Zhukovskaya, KrasaSevera, Griotte ostgejmsky, Kentskaya, Krupnoplodnaya Gorshkova, Shirpotreb chernaya, Nadezhda Krupskaya, Ujfeherto furtos, and others.

During the creation of varieties the pretty good results were achieved by sowing of seeds of different origin received form free pollination. In the combinations presented below the effect of environmental factors could favor the occurrence of positive transgressions and the occurrence in $\mathrm{F} 2$ and in next generations of genotypes with valuable 
selection features, the complex of which substantiated their definition as the elites (Figures 1--5).

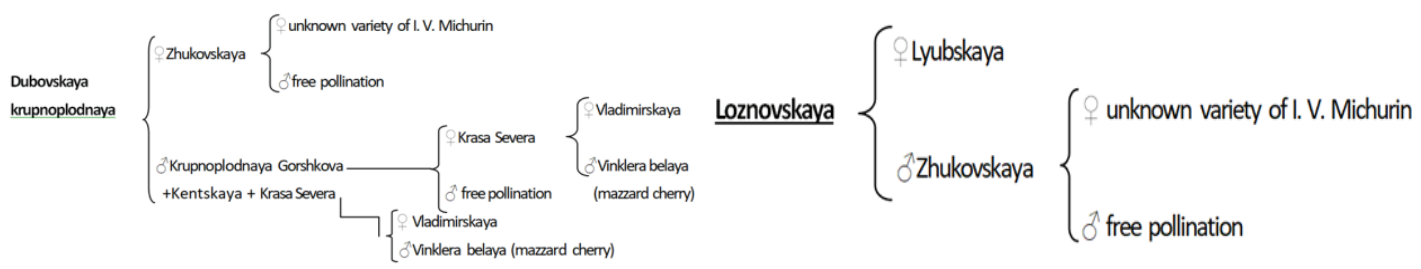

Figure 1: Selection model for optimization of varieties Dubovskaya krupnoplodnaya and Loznovskaya on the basis of genealogical analysis.

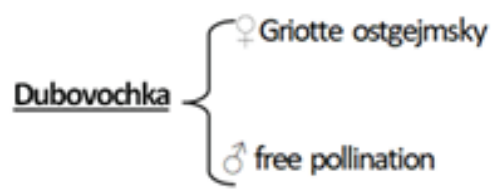

Figure 2: Selection model for optimization of variety Dubovochka on the basis of genealogical analysis.

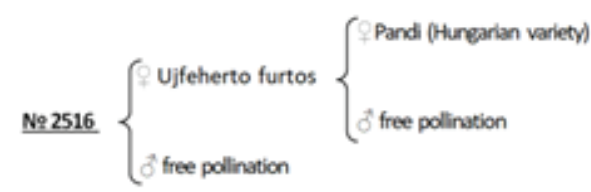

Figure 3: Selection model for optimization of the elite 2516 on the basis of genealogical analysis.

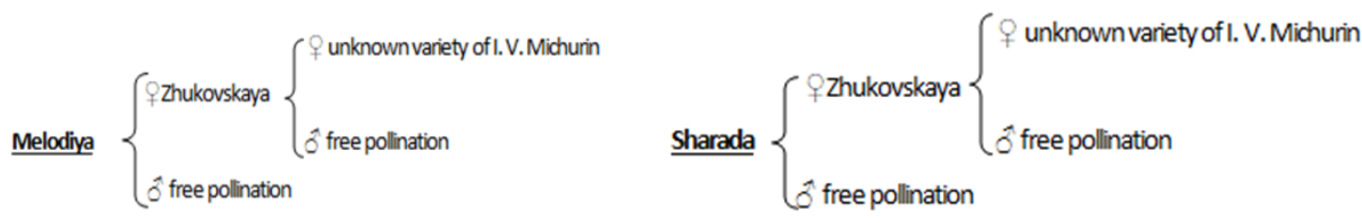

Figure 4: Selection model for optimization of varieties Melodiya and Sharada on the basis of genealogical analysis.

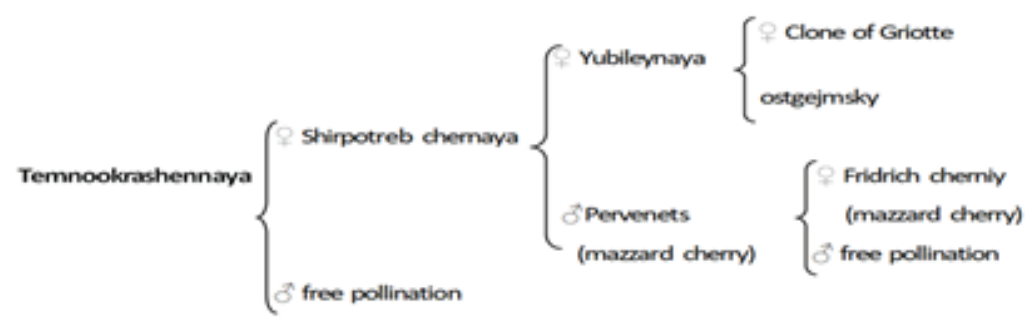

Figure 5: Selection model for optimization of the variety Temnookrashennaya on the basis of genealogical analysis.

These combinations prove the fact that the $F_{2}$-hybrids developed by free pollination of $F_{1}$-hybrids presented in the given above combinations by varieties Zhukovskaya, Griotte ostgejmskiy, Ujfeherto furtos, and Temnookrashennaya, show the best matching and 
development of valuable industrial characteristics [16]. The qualitative characteristics of the new varieties and their parent forms are given in the Table 1.

TABLE 1: Industrial and biological characteristics of the new varieties of sour cherry and their parent forms, NVNIISKH.

\begin{tabular}{|c|c|c|c|c|c|c|c|c|}
\hline \multirow[t]{2}{*}{ Variety } & \multirow{2}{*}{$\begin{array}{l}\text { Date of } \\
\text { ripening }\end{array}$} & \multirow{2}{*}{$\begin{array}{l}\text { Weight } \\
\text { of fruits, } \\
\mathrm{g}\end{array}$} & \multicolumn{3}{|c|}{ Estimation of fruits, number } & \multicolumn{3}{|c|}{ Chemical composition \% } \\
\hline & & & $\begin{array}{c}\text { habit } \\
\text { attract- } \\
\text { iveness }\end{array}$ & $\begin{array}{c}\text { eating } \\
\text { qualities }\end{array}$ & $\begin{array}{c}\text { total } \\
\text { estimat- } \\
\text { ion }\end{array}$ & sugars & acid & $\begin{array}{l}\text { sugars/ } \\
\text { acid }\end{array}$ \\
\hline Dubovochka & 20.06 & 3,2 & 4,0 & 4,5 & 4,3 & 12,69 & 1,51 & 8,4 \\
\hline $\begin{array}{l}\text { Dubovskaya } \\
\text { krupnoplodnaya }\end{array}$ & 20.06 & 5,0 & 4,8 & 4,5 & 4,6 & 10,15 & 1,37 & 7,4 \\
\hline Kentskaya, p & 20.06 & 3,6 & 4,3 & 4,0 & 4,1 & 10,53 & 1,44 & 7,3 \\
\hline Krasa Severa, $p$ & 25.06 & 4,5 & 4,5 & 3,5 & 4,0 & 9,32 & 1,65 & 5,7 \\
\hline Melodiya & 25.06 & 3,2 & 4,5 & 4,5 & 4,5 & 11,14 & 1,53 & 7,3 \\
\hline Loznovskaya & 25.06 & 4,6 & 5,0 & 5,0 & 5,0 & 8,97 & 0,95 & 9,4 \\
\hline Lubimitsa & 25.06 & 4,3 & 4,8 & 4,2 & 4,5 & 9,51 & 1,13 & 8,4 \\
\hline $\begin{array}{l}\text { Shirpotreb } \\
\text { chernaya,p }\end{array}$ & 25.06 & 4,0 & 4,0 & 4,5 & 4,2 & 11,02 & 1,31 & 8,4 \\
\hline Temnookrashennaya & 25.06 & 4,2 & 4,5 & 4,5 & 4,5 & 11,44 & 1,29 & 8,9 \\
\hline Zhukovskaya, p & 05.07 & 3,6 & 4,5 & 4,8 & 4,6 & 10,32 & 1,49 & 6,9 \\
\hline $\begin{array}{l}\text { Krupnoplodnaya } \\
\text { Gorshkova }\end{array}$ & 05.07 & 4,5 & 4,5 & 3,0 & 3,7 & 9,21 & 1,56 & 5,9 \\
\hline Griotte ostgejmsky,p & 05.07 & 3,4 & 4,5 & 4,0 & 4,3 & 10,82 & 1,35 & 8,0 \\
\hline Sharada & 10.07 & 5,6 & 5,0 & 4,8 & 4,9 & 11,48 & 1,38 & 8,3 \\
\hline Elite 2516 & 10.07 & 5,0 & 4,5 & 4,5 & 4,5 & 11,58 & 1,24 & 9,3 \\
\hline Ujfeherto furtos, $p$ & 15.07 & 4,0 & 4,5 & 4,2 & 4,3 & 10,89 & 1,21 & 9,0 \\
\hline Lyubskaya, p & 20.07 & 4,0 & 4,0 & 3,0 & 3,5 & 9,51 & 1,81 & 5,2 \\
\hline
\end{tabular}

Note: $\mathrm{p}$-- varieties used as parent forms.

The presented data is also confirmed by the results of other selection centers which received new high quality varieties with the participation of the above mentioned forms of cherry: Shokoladnitsa, Rovesnitsa, Turgenevka, Bystrinka, and others (All-Russia Scientific-Research Institute of Selection of Fruit Crops), Tamaris (All-Russia ScientificResearch Horticultural Institute named after I. V. Michurin), Bulatnikovskaya, Malinovka, Brunetka, Pamyat' Yenikeyeva, Rastorguyevskaya (All-Russia Selection and Technology Institute of Horticulture and Nursery Gardens -- VSTISP), Rossoshanskayachernaya, Chernayakrupnaya (Rossoshanskaya Zonal OSS), DesertnayaTikhonovoj, Pamyat` 
Shcherbakova, Kharitonovskaya (All-Russia Scientific-Research Institute of Genetics and Selection of Fruit Crops), Solidarnost` (Ukraine) [17, 18].

During the selection of plum, the most effective was the hybridization of local varieties of the Volga region and some Central Russian varieties, in particular, Ternoslivletniy, Ternoslivosenniy, Volzhskayasinyaya, Skorospelkakrasnaya with some adaptive high quality foreign varieties -- Rannyayasinyaya, Ispolinskaya, Victoria, Reine-claudeAltana, Anna Spaet (Table 2).

TABLE 2: Characteristics of new varieties of plum selected in the Dubovsky control station.

\begin{tabular}{|c|c|c|c|c|c|c|c|c|c|}
\hline \multirow[t]{2}{*}{ Variety } & \multirow[t]{2}{*}{ Origin } & \multirow{2}{*}{$\begin{array}{l}\text { Date of } \\
\text { ripen- } \\
\text { ing }\end{array}$} & \multirow{2}{*}{$\begin{array}{l}\text { Weight } \\
\text { of fruit, } \\
\mathrm{g}\end{array}$} & \multicolumn{3}{|c|}{$\begin{array}{l}\text { Estimation of quality of } \\
\text { fruits, number }\end{array}$} & \multicolumn{3}{|c|}{$\begin{array}{c}\text { Chemical composition } \\
\text { of fruits, } \%\end{array}$} \\
\hline & & & & $\begin{array}{l}\text { habit } \\
\text { attract- } \\
\text { iveness }\end{array}$ & $\begin{array}{l}\text { eating } \\
\text { qualit- } \\
\text { ies }\end{array}$ & $\begin{array}{l}\text { total } \\
\text { estimat- } \\
\text { ion }\end{array}$ & $\begin{array}{l}\text { amount } \\
\text { of } \\
\text { sugars }\end{array}$ & acid & $\begin{array}{l}\text { sugars/ } \\
\text { acid }\end{array}$ \\
\hline Bogatyrskaya & $\begin{array}{l}\text { Ispolinskaya } \times \\
\text { Volzhskaya } \\
\text { sinyaya }\end{array}$ & 26.08 & 32,0 & 4,5 & 4,8 & 4,7 & 15,16 & 0,82 & 16,1 \\
\hline $\begin{array}{l}\text { Vengerka } \\
\text { dubovskaya }\end{array}$ & $\begin{array}{l}\text { Volzhskaya } \\
\text { sinyaya } \times \\
\text { Ternoslivletniy }\end{array}$ & 15.09 & 23,0 & 4,2 & 4,3 & 4,3 & 11,62 & 1,07 & 11,1 \\
\hline $\begin{array}{l}\text { Vengerka } \\
\text { korneyevskaya }\end{array}$ & $\begin{array}{l}\text { Bogatyrskaya } \times \\
\text { Volgogradskaya }\end{array}$ & 22.08 & 34,0 & 4,5 & 5,0 & 4,8 & 12,83 & 0,96 & 13,4 \\
\hline Dubovchanka & $\begin{array}{l}\text { Skorospelka } \\
\text { krasnaya } \times \\
\text { Persikovaya }\end{array}$ & 30.07 & 25,0 & 4,5 & 4,5 & 4,5 & 8,67 & 1,82 & 4,8 \\
\hline lyul’skaya & $\begin{array}{l}\text { Rannyaya sinyaya } \\
\times \text { Ternoslivletniy }\end{array}$ & 30.07 & 25,0 & 4,0 & 4,2 & 4,2 & 8,22 & 1,68 & 4,9 \\
\hline Marsianka & $\begin{array}{l}\text { Ispolinskaya } \times \\
\text { free pollination }\end{array}$ & 20.07 & 27,0 & 4,3 & 4,5 & 4,5 & 10,03 & 1,84 & 5,5 \\
\hline Mechta & $\begin{array}{l}\text { Rannyaya sinyaya } \\
\times \text { free pollination }\end{array}$ & 10.09 & 43,0 & 5,0 & 4,8 & 4,9 & 14,98 & 0,35 & 4,28 \\
\hline Suvenirnaya & $\begin{array}{l}\text { Reine-claude } \\
\text { Altana } \times \text { free } \\
\text { pollination }\end{array}$ & 01.09 & 50,2 & 4,8 & 4,8 & 4,8 & 9,07 & 1,34 & 7,9 \\
\hline Tatyana & $\begin{array}{l}\text { Reine-claude } \\
\text { Altana } \times \text { free } \\
\text { pollination }\end{array}$ & 05.09 & 41,0 & 4,5 & 4,7 & 4,6 & 9,96 & 0,87 & 14,9 \\
\hline
\end{tabular}

The majority of elites were developed by the above mentioned method, including regionalized varieties that were not inferior in their winter resistance to local varieties of the Volga region, and in addition, they missed such imperfections of the local varieties as small fruits and their low eating qualities [19].

The good results were also obtained during the course of repeated hybridization of the new varieties of plum created with the participation of the local varieties of the 
Volga region with the most adaptive foreign varieties, such as, Victoria, Anna Spaet, Ispolinskaya, Reine-claudeAltana, and a number of others [20].

The promising results were received also during the hybridization between the new varieties selected in the Volga region. The example should be the variety -Vengerkakorneyevskaya, created by crossing of the Bogatyrskaya and Volgogradskaya varieties (Figure 6).

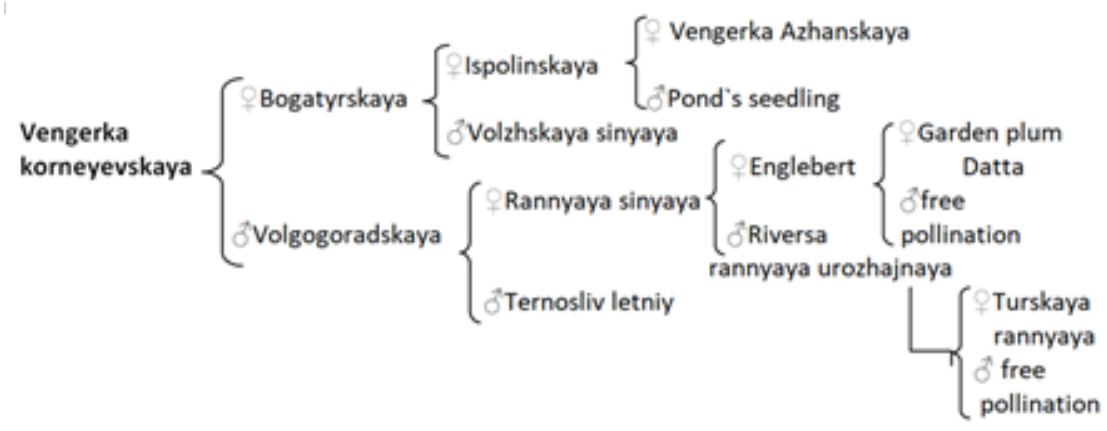

Figure 6: Selection model for optimization of the variety Vengerka korneyevskaya on the basis of genealogical analysis.

The selection model for optimization of the variety Vengerka korneyevskaya on the basis of genealogical analysis of the donors makes it possible to consider the varieties of plum of the Volga region to be the donors for winter- and drought-resistance, and to determine the donors for a number of selection characteristics among the introduced foreign varieties, that is confirmed during the development of the second generation of hybrids which stand out for their being the perspective elites and new varieties (Table 3).

A number of promising elites were determined also among the seedlings from free pollination of some introduced southern and foreign varieties of plum. The specific environmental conditions of the Low Volga region provide the formation and manifestation of the complex of characteristics of single seedlings of plum that is connected with the adaptation to the local conditions and the formation of genotypes with the characteristics which determine the quality of fruits. As the majority of hybrids from free pollination are in fact $F_{2}$-hybrids and their pollinators are local winter-resistant varieties, so their seed generation develops to the full the genetic potential of the parent forms which is caused by the effect of specific local conditions of cultivation and results in development of positive transgressions.

The practicability of the use of new varieties selected in the Low Volga region is confirmed by development of the variety Kubanskaya yubileynaya in the Krymskaya OSS of VIR. The new variety originated from the variety Zaynap that is the seedling of the variety Jefferson developed in the Volgogradskaya control station -- branch of 
TABLE 3: Donor characteristics of parent genotypes appeared in new varieties of plum.

\begin{tabular}{|c|c|c|c|c|c|c|c|c|}
\hline Variety-donor & $\begin{array}{l}\text { Winter- } \\
\text { resist- } \\
\text { ance of } \\
\text { wood }\end{array}$ & $\begin{array}{l}\text { Winter- } \\
\text { resist- } \\
\text { ance of } \\
\text { flower } \\
\text { buds }\end{array}$ & $\begin{array}{l}\text { Drought- } \\
\text { resisit- } \\
\text { ance }\end{array}$ & $\begin{array}{l}\text { Self- } \\
\text { fertility }\end{array}$ & $\begin{array}{l}\text { Early } \\
\text { ripeness }\end{array}$ & $\begin{array}{l}\text { Late } \\
\text { ripeness }\end{array}$ & $\begin{array}{l}\text { Large- } \\
\text { fruits }\end{array}$ & $\begin{array}{c}\text { High } \\
\text { eating } \\
\text { qualities } \\
\text { of fruits }\end{array}$ \\
\hline \multicolumn{9}{|c|}{ Local varieties of the Volga region and old Russian varieties } \\
\hline Volzhskaya sinyaya & + & - & - & + & - & + & - & - \\
\hline $\begin{array}{l}\text { Skorospelka } \\
\text { krasnaya }\end{array}$ & + & + & - & + & - & - & - & - \\
\hline Ternosliv letniy & + & + & + & + & - & - & - & - \\
\hline Ternosliv osenniy & + & + & + & + & - & + & - & - \\
\hline \multicolumn{9}{|c|}{ Foreign varieties } \\
\hline $\begin{array}{l}\text { Vengerka } \\
\text { italyanskaya }\end{array}$ & - & - & - & - & + & + & + & + \\
\hline Victoria & + & - & - & - & + & - & + & - \\
\hline Ispolinskaya & - & - & - & - & - & - & + & + \\
\hline Persikovaya & - & - & - & + & + & - & + & - \\
\hline Rannyaya sinyaya & + & - & - & - & + & - & - & - \\
\hline $\begin{array}{l}\text { Reine-claude } \\
\text { Altana }\end{array}$ & - & - & + & - & - & + & + & + \\
\hline Anna Spaet & - & - & + & - & - & + & + & + \\
\hline
\end{tabular}

VIR. The new variety Kubanskayayubileynaya (Zaynap x Alvena) is characterized by high quality of fruits and their big size, as well as by sufficient winter-resistance and productivity [15].

By hybridization with the varieties of the Volga region and by use of the seedlings from free pollination, the good results were achieved with the participation of varieties of different origin, the genotypes of which dispose of big potential resources of the characteristics of different varieties involved (Figure 7).

The new varieties of cherries and plums can be considered as the sources of valuable characteristics for the selection of stone crops both in the Low Volga region and in the other regions of Russia, in the southern and central zones of fruit-growing. The genotypes that show the combination of adaptability and other valuable characteristics are of a particular significance. The above mentioned new sources dispose of the following characteristics:

- early ripeness: varieties of plum -- Dubovchanka, Marsianka; cherry -- Dubovochka;

- self-fertility: variety of plum -- Vengerka dubovskaya; cherry -- Loznovskaya, elite 2516; 


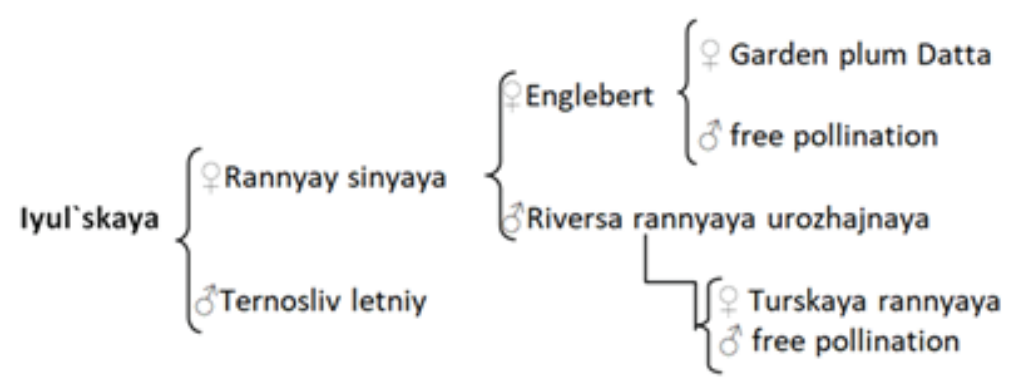

Figure 7: Selection model for optimization of the variety lyul'skaya on the basis of genealogical analysis.

- large-fruits: varieties of plum -- Volgogradskaya, Bogatyrskaya, Vengerka korneyevskaya, Tatyana, Suvenirnaya; cherry -- Loznovskaya, Sharada, 2516;

- high eating qualities of fruits: varieties of plums -- Bogatyrskaya, Vengerka korneyevskaya, Marsianka, Tatyana; cherry -- Loznovskaya, Lyubimitsa.

The integrated donors might be considered to be the varieties of plum -- Bogatyrskaya and Volgogradskaya, and varieties of cherry -- Loznovskaya, Sharada, elite 2516.

\section{Conclusion}

The environmental conditions of the Low Volga region provide the development of winter resistance in combination with large-fruit and good eating qualities of fruits of the hybrid seedlings of plum.

The monitoring on the basis of genealogical analysis and selection works with sour cherry using a number of forms (Zhukovskaya, Lyubskaya, KrasaSevera, Shirpotreb chernaya, Ujfeherto furtos) resulted in the development of a selection model for optimization of gene bank and in determination of new varieties and elites -- Loznovskaya, Dubovskaya krupnoplodnaya, Dubovochka, Peskovatskaya, Melodia, Lyubimitsa, Temnookrashennaya, Sharada, and elite 2516, -- that provide a better assortment of this crop in the Low Volga region, especially assortment of adaptive, high productive, high quality varieties of the universal use.

There was confirmed the fact that the $F_{2}$-hybrids created with the free pollination of $F_{1}$-hybrids represented in our research by polymorphic varieties Zhukovskaya, Griotte ostgejmsky, and Ujfeherto furtos, dispose of better combination and perform better economic industrial characteristics which combination and performance by the initial forms either is not so evident or those characteristics are not combined and not displayed at all. 
The regionalized assortment for the Low Volga region has been enriched by the six varieties; the varieties Temnookrashennaya and Sharada are being tested; elite 2516 are passed to the State Varieties Commission. All the varieties developed should be appropriate to use as the integrated donors for the selection programs on the further improvement of sour cherry.

The works on selection of garden plum resulted in development of a number of winterresistant varieties with sufficient industrial and biological characteristics which improve considerably the assortment of plum in the Low Volga region. The local varieties of the Volga region -- Volzhskaya sinyaya, Ternosliv letniy, and Ternosliv osenniy -- were determined to be the donors for winter-resistance. The new varieties of plum of the domestic selection of NVNIISKH, such as, Bogatyrskaya, Volgogradskaya, Vengerka korneyevskaya, are defined as the sources of valuable selection characteristics -- largefruits, high qualities of fruits, and others, in combination with their winter-resistance.

The promising trends are the hybridization of the local and new varieties of plum of the Volga region with adaptive foreign varieties of plum, in particular, with Rannyaya sinyaya, Ispolinskaya, Reine-claude Altana, and the development of selection models for their optimization.

\section{Conflict of Interest}

The authors have no conflict of interest to declare.

\section{References}

[1] Semenyutina, A.V., Podkovyrov, I.Y., Huzhakhmetova, A.Sh., Semenyutina, V.A., Podkovyrova, G.V. (2016). Mathematical justification of the selection of woody plants biodiversity in the reconstruction of objects of gardening. International Journal of Pure and Applied Mathematics, vol. 110, no. 2. pp. 361--368. DOI 10.12732/ijpam.v110i2.10

[2] Semenyutina, A.V., Svintsov, I.P., Huzhakhmetova, A.Sh., Semenyutina, V.A. (2018). Regulations of safe and sustainable use of biodiversity of woody plants in protective afforestation. Journal of Agriculture and Environment, no. 3(7). DOI. org/ 10.23649/ jae.2018.3.7.3

[3] Korneyev, R.V. (1992). Cherry and plum. Volgograd, 95 p.

[4] Yeremin, G.V. (2003). Plum and cherry-plum. Kharkov: Folio; Moscow: AST publ., Ltd, 302 p. 
[5] Yeremin, G.V. (2007). Golden thistle and blackthorn. Moscow: Nikola-press Publ.; Folio-public Publ., $157 \mathrm{p}$.

[6] Gintsenberg, A.A. (1914). Cherry and its industrial plantings. Part I. Free appendix to the journal "Horticulture". Petrograd, 109 p.

[7] Kalashnikova, L.I. (1965). Results of fifteen years of study of varieties of cherry and plum. Scientific papers of the Volgograd research station of VIR, vol. 4, pp. 56--63. Volgograd.

[8] Kolesnikova, A.F. (2003). Cherry.Mazzard cherry. Kharkov: Folio, 255 p.

[9] Solonkin, A.V. (2015). Cherry. Selection of new varieties in the Volgograd region. Volgograd: NVNIISKH, Sphera Ltd, $128 \mathrm{p}$.

[10] Program And Methods Of Variety Study Of Fruit, Berry, And Nut Crops. (1999). Ed. by academician of RASKHN Ye.N. Sedov and Dr. Sci. (Agr.) T.P. Ogol tsova. Orel: VNIISPK, $608 \mathrm{p}$.

[11] Program and Methods of Selection Of Fruit, Berry, And Nut Crops. (1995). Ed. by academician of RASKHN Ye.N. Sedov. Orel: VNIISPK.

[12] Yeremin, G.V., Isachkin, A.V. et al. (2004). Common and partial selection and variety investigation of fruit and berry crops. Moscow: Mir, $422 \mathrm{p}$.

[13] Yeremin, G.V., Dubravina, I.V. (2017). Use of genealogical and genome analysis during the estimation of initial material in selection of fruit crops. Modern methodology, instruments for estimation and choice of selection material of garden crops and grape. Krasnodar, pp. 181--188.

[14] Solonkin, A.V. (2017). Creating the varieties of cherry in the Low Volga region. Fruit and berry growing in Russia: collected scientific papers of VSTISP, vol. XXXXVIII, P. I, pp. 240--245. Moscow.

[15] Yeremin, G.V., Dubravina, I.V., Kovalenko, N.N., Gasanova, T.A. (2016). Preliminary selection of fruit crops. Krasnodar: State Agrarian University of Kuban -- KubGAU, $335 \mathrm{p}$.

[16] Solonkin, A.V. (2017). Improvement of the assortment of sour cherry in the Low Volga region. Proceedings of the Agrouniversity complex of the Low Volga region: Science and higher professional education, no. 4(48), pp. 147--154.

[17] Dzhigadlo, Ye.N. (2009). Improvement of methods of selection, development of varieties of cherry and mazzard cherry, their rootstocks with ecological adaptation to the conditions of the Central Russia. Orel: All-Russia Scientific-Research Institute of Selection of Fruit Crops --VNIISPK, 268 p.

[18] Pomology, V. (2008). Stone fruit crops, ed. by acad. Ye.N. Sedov. Orel: VNIISPK, $592 \mathrm{p}$. 
[19] Solonkin, A.V., Yeremin, G.V. (2017). Use of local and new varieties of the Low Volga region when selection of adaptive varieties of plum. Scientific journal of KubGAU, December, no. 134(10), pp. 368--378.

[20] Zurawicza, E. (2003). Pomologia. Odmianoznaws two roslinsadowniczychapeks. Warszawa, $271 \mathrm{p}$.

[21] lezzoni, A.F. (2008). Cherries. Temperate Fruit Crop Breeding: Germplasmto Genomics, pp. 151--175.

[22] Horvath, A., Zanetto, A., Tavaud, M., Christmann, H., Laigret, F. (2008). Origin of sour cherry (Prunuscerasus L.) genomes (Conference Paper). Acta Horticulturae. 5th International Cherry Symposium, vol. 795, part 1, pp. 131--136. Bursa, Turkey. 